\title{
Editorials
}

\section{Factors affecting onset and course of psychoses}

\section{Editoriali}

I fattori che influenzano l'insorgenza ed il decorso delle psicosi

\author{
MICHELE TANSELLA, Editor and PAOLA DAZZAN, Guest Editor
}

The three Editorials that appear on this issue of Epidemiologia e Psichiatria Sociale discuss factors that affect the onset and course of psychosis. This is a very important topic and over the last few years there has been growing interest in the identification of factors that may predict which people will develop psychosis (and possibly different forms of psychosis), and/or may affect the course of these incapacitating illnesses, in an attempt to eventually improve their outcome. Among the pioneers of research into individuals at increased risk of psychosis is the research group based at University of Melbourne. From this group, Stephen Wood and Colleagues are the authors of the first editorial in this series, "The transition to psychosis: risk factors and brain changes". In the Editorial, they focus on the neurobiology of the transition period from an "at risk" mental state to clinically defined psychosis. In particular, they report evidence for cognitive deficits in prefrontal cortical function, and brain structural grey matter volume reductions in the orbitofrontal and parahippocampal cortices, which may be more pronounced in subjects who later become psychotic.

The second Editorial is by Chiara Samele and is entitled "Factors leading to poor physical health in people with psychosis". This work evaluates an aspect that is frequently neglected in the evaluation of the well-being of psychotic patients. Considering that individuals with major mental illnesses notoriously have poor physical health, this is a very important issue not only from a psychiatric care perspective, but also from a public health perspective. This Editorial discusses the extent of the
I tre Editoriali presentati in questo numero di Epidemiologia e Psichiatria Sociale discutono i fattori che influenzano l'esordio e il decorso delle psicosi. Si tratta di un argomento molto importante, che nel corso degli ultimi anni è stato oggetto di vari studi. In particolare, grande attenzione è stata posta ad identificare $\mathrm{i}$ fattori in grado di predire quali individui siano destinati a sviluppare una psicosi (ed eventualmente diverse forme di psicosi) e quali fattori abbiano un effetto sul decorso di un disturbo grave come la psicosi, anche nella speranza di poterne migliorare l'esito. Tra gli iniziatori delle ricerche sugli individui ad aumentato rischio di sviluppare psicosi, si colloca un gruppo di ricerca della University of Melbourne. Fanno parte di questo gruppo Stephen Wood e gli altri Autori del primo Editoriale di questa serie, intitolato "The transition to psychosis: risk factors and brain changes". Essi discutono i fattori neurobiologici che rendono più o meno probabile il.passaggio dallo stato di "aumentato rischio" allo stadio di psicosi conclamata. In particolare presentano le evidenze che suggeriscono la presenza di deficit cognitivi delle funzioni prefrontali, e di anomalie della struttura cerebrale a livello di corteccia orbitofrontale e paraippocampale, negli individui destinati a sviluppare la psicosi conclamata.

Il secondo editoriale dal titolo "Factors leading to poor physical health in people with psychosis" è stato scritto da Chiara Samele. Questo lavoro valuta un aspetto spesso trascurato nella valutazione del benessere dei pazienti con psicosi: la loro salute fisica. Si tratta di un argomento importante non solo per l'assistenza psichiatrica, ma anche per la salute pubblica in generale, quando si consideri che i pazienti con disturbi mentali maggiori soffrono spesso di 
problem, and also issues related to its detection, management and prevention, providing interesting recommendations for improving physical health care.

Finally, in the last Editorial of this series (written in Italian), Vittorio Di Michele and Francesca Bolino discuss the factors leading to poor social outcome in psychosis, in their paper entitled "Factors leading to bad social outcome in subjects with psychosis". They analyse and discuss evidence on factors affecting outcome, and their potential role in an integrated therapeutic approach. It is particularly interesting that these authors include theory of mind and social cognition as factors relevant to social functioning, and discuss their importance for rehabilitation programs.

We believe that these three Editorials provide an excellent updated academic discussion on factors affecting the onset and the course of psychosis, while also offering an interesting insight into their relevance at a clinical level, and into opportunities for implementing changes in everyday care. una scarsa salute fisica. In questo editoriale, C. Samele discute non solo la portata del problema, ma anche gli aspetti legati alla sua identificazione, gestione, e prevenzione, fornendo allo stesso tempo alcune raccomandazioni sul come migliorala.

Infine, Vittorio Di Michele e Francesca Bolino presentano un Editoriale (in italiano) dal titolo "Factors leading to bad social outcome in subjects with psychosis". Essi presentano le evidenze su diversi fattori che hanno conseguenze sull'outcome sociale delle psicosi, e sul loro potenziale ruolo in un approccio terapeutico integrato. Abbiamo trovato particolarmente interessante che questi autori abbiano incluso, tra i fattori importanti nel determinare l'outcome sociale, anche la "teoria della mente" $\mathrm{e}$ in generale la cognizione sociale, e abbiano discusso il ruolo di questi fattori nei programmi di riabilitazione.

Gli Editoriali pubblicati in questo numero di EPS forniscono sia un eccellente aggiornamento delle evidenze sui fattori di rischio per la psicosi, sia un interessante insight sul ruolo che questi fattori possono svolgere nella pratica clinica quotidiana. 